\title{
Exploring the Coping Strategies that Improve Resiliency among Flood Victims in Kelantan, Malaysia
}

\author{
Noremy Md Akhir, Mohammad Rahim Kamaluddin, Aizan Sofia Amin, Rusyda Helma Mohd, \\ Nur Hafizah Md Akhir
}

\begin{abstract}
The major flood incident in Kelantan in 2014 was an unexpected disaster that caused physical destructions as well as psychological problems. A number of literatures have highlighted coping strategies as one of the resilience factor that can actually protect the flood victims from experiencing psychological distress. With this in mind, this study was conducted explore the coping strategies used by the flood victims in Kelantan. A total of 28 flood victims were selected as potential informants in this study based on predetermined inclusion criteria using a purposive sampling method. A qualitative research design using case study approach was employed in this study. In-depth and face to face interview sessions were carried out using an interview guide. The interviews were analyzed using thematic analyses and four main coping strategies were emerged as themes namely, problem focused coping, emotion focused coping, religious coping and maladaptive coping strategy. The coping strategies used by the victims to improve resiliency were discussing from the context of psychological and social work perspectives. It is anticipated the findings of this study would provide valuable information for the development of crisis intervention programs and modules.
\end{abstract}

Index Terms: Coping strategy, resiliency, flood victims, flood disaster.

\section{INTRODUCTION}

The major flood that occurred in December 2014 in Malaysia badly affected the Kelantan state. This unexpected phenomenon caused more than 120,000 flood victims to evacuate immediately to the nearby relief center. In addition, it was reported that 11 people were killed in this tragic moment while an estimation of 2374 houses were completely destroyed. Besides that, this tragic incident also resulted in destruction of government assets, public as well as private properties and infrastructures which led to a total estimation of more than 1 billion Malaysian Ringgit [1]. It is very common that individuals experience several mental distresses such as post-traumatic disorders due to sudden and unexpected event. Past researches have highlighted that

\footnotetext{
Revised Manuscript Received on September 25, 2019

Noremy Md. Akhir, Senior Lecturer, National University of Malaysia, Selangor, Malaysia.

Mohammad Rahim Kamaluddin, Senior Lecturer, National University of Malaysia, Selangor, Malaysia.

Aizan Sofia Amin, Senior Lecturer, National University of Malaysia, Selangor, Malaysia.

Rusyda Helma Mohd, Lecturer, National University of Malaysia, Selangor, Malaysia.

Nur Hafizah Md. Akhir, PhD student, University of Sciences Malaysia, Penang, Malaysia.
}

post-traumatic cases are very common among flood victims especially among those who loss properties and shelters [2][3]. The psychological distress faced by the victims result in various negative impacts including decline in physical abilities as well as emotional disturbance. This eventually expected to erode the mental well-being of flood victims. A number of studies have been conducted to investigate the psychological distress such as trauma and other form distress among flood victims [4][5]. A study found that destruction, loss and damage of properties due to flood disaster led to negative impacts on psychological, emotional as well as social components among flood victims [6]. Similarly, few local studies also focused on psychological and mental health issues as the consequences of natural disaster have been carried out [3][7][8]. In addition, studies have also reported that flood victims often experienced some psychological problems such as sadness, stress and depression [3][8]. Although a number of studies have been conducted in relation to psychological distress among flood victims, the victims still depend on the counselors and psychologists in terms of the the psychological aid such as emotional coping strategies. This in turn led to slow recovery and failure in coping among the flood victims.

Previous studies have also concluded that resiliency could be one of the potential factors to protect the victims from experiencing psychological problems [7][9]. A study on emotional stress and resiliency among 160 school students who affected from the flood in Kelantan found that there is a negative correlation with trauma and resiliency in which respondents with better resiliency level experience lesser trauma compared to the counterparts [7]. While the above statement was proven with quantitative approach, an in-depth research using qualitative research design is needed as it can provide better insight on how resiliency can actually help the victim from experiencing psychological problems such as trauma. With this in mind, this study explores the coping strategies used by the flood victims that help them to be resilient during the recovery phase of flood. Researchers believe that coping strategy is one form of resiliency which protects the flood victims from experiencing psychological distress. 


\section{METHODOLOGY}

The present study employs a qualitative research design using case study approach. A qualitative research is a widely used research design as it can help the researchers to produce rich, informative yet complex data [10]. This research design focuses on the clear understanding and in-depth explanation on the phenomena and not based on measurement or calculation. Meanwhile the case study approach involves in-depth and systematic data collection on individual behavior [11].

With regard to selection of samples, the informants were recruited based on purposive sampling technique for face-to-face in-depth interview sessions. The informants were purposely chosen based on the inclusion criteria. In general, inclusion criteria are the conditions required to qualify an individual to be selected as informant [12]. As such, a number of inclusion criteria predetermined by the researchers are as follows:

1) Flood victims who have experienced flood disasters in December 2014 in Kelantan, Malaysia;

2) Flood victims who had total loss of house and properties due to flood;

3) 18 years old and above;

4) Mentally fit (no history of mental disorders); and

5) Malaysian.

The interview guide was developed by the researchers in the form of semi structure questions and the researcher acted as instrument. In the beginning of the data collection phase, the researchers estimated a sample size of 25 to 30 flood victims; however, after interviewing the $26^{\text {th }}$ informant, the researchers were found that the data were saturated. As an effort to reconfirm the saturation of data, two more interviews were carried out with $27^{\text {th }}$ and $28^{\text {th }}$ informants; and found there was no any new themes were emerged. As such, the researchers have concluded the study with 28 informants as the saturation point was met. The entire interview sessions were audio recorded with the permission from the informants. As an ethical procedure, signed consents were obtained from the informants prior to their recruitment in this study. Each interview session was ranged between one to two hours. Informants were informed regarding the disposal of the given information at the end of the study. Their identity and responses were portrayed as anonymous and kept secret in order to sustain the honesty and validity of responses.

The interviews were transcribed into verbatim for the data for the purpose of analysis. The data were analyzed using the thematic analysis which consists of five main processes: familiarizing the data, producing initial code, finding the theme, investigating the theme and reinterpreting and renaming the theme [13]. Table 1.0 depicts the summary of the methodology used in this study.

Table 1.0

Summary of Methodology

\begin{tabular}{ll}
\hline Research method & Qualitative approach \\
Research design & Case study \\
Research sampling & Purposive sampling \\
Sample/Informant & 28 flood victims \\
Data collection technique & Face-to-face \& \\
& In-depth interview
\end{tabular}

Research instrument

Data Analysis

Interview guideline

(semi structure)

Researcher

Thematic analysis

\section{DEMOGRAPHY}

This study involved 28 flood victims who experienced total loss of houses and properties due to the major flood in December 2014 in Kelantan, Malaysia. There are 16 females and 12 male informants participated in this study and their age ranged between 24 and 91 years old. In relation to ethnicity, 26 informants are Malay Muslims and two informants are Chinese Buddhists (informant 2 and informant 12) involved in this study. Majority of the informants shows education level up to secondary school level. Majority of the informants worked as semi-skilled workers. Table 2.0 below summaries the demography profile of the informants in this study.

Table 2.0

Demography Profile of Informants

\section{(I) Gender Age Education level Occupation}

\begin{tabular}{lllll}
\hline 1 & Female & 63 & None & None \\
2 & Male & 77 & Primary school & None \\
3 & Female & 40 & Primary school & Housekeeping \\
4 & Female & 91 & None & None \\
5 & Male & 45 & Secondary school & Small business \\
6 & Male & 41 & Secondary school & Car mechanic \\
7 & Female & 29 & Secondary school & Food seller \\
8 & Female & 51 & Primary school & Maid \\
9 & Male & 66 & Primary school & Self worker \\
10 & Female & 47 & Secondary school & Rubber tapper \\
11 & Female & 42 & Secondary school & Shop assistant \\
12 & Male & 54 & Secondary school & Furniture seller \\
13 & Male & 49 & Secondary school & Contractor \\
14 & Female & 48 & Secondary school & Tailor \\
15 & Male & 51 & Secondary school & Contractor \\
16 & Male & 56 & Secondary school & Entrepreneurs \\
17 & Female & 47 & Secondary school & Food seller \\
18 & Female & 40 & Secondary school & Shop assistant \\
19 & Male & 24 & Secondary school & Shop assistant \\
20 & Female & 44 & Secondary school & Food seller \\
21 & Male & 45 & Secondary school & Contractor \\
22 & Female & 36 & Secondary school & Shop assistant \\
23 & Female & 47 & None & Food seller \\
24 & Male & 36 & Secondary school & Gardener \\
25 & Male & 54 & Secondary school & Rubber tapper \\
26 & Female & 30 & Secondary school & Rubber tapper \\
27 & Female & 42 & Secondary school & Food seller \\
28 & Female & 37 & Primary school & None \\
& & & & \\
\hline
\end{tabular}

$* \mathrm{I}=$ Informant

\section{FINDINGS AND DISCUSSION}

In general, coping strategy can be referred as an action (behavior) and thoughts (cognitively conscious or unconscious) practiced by the victims to deal with a threatening situation or any crisis situation (disasters). It is

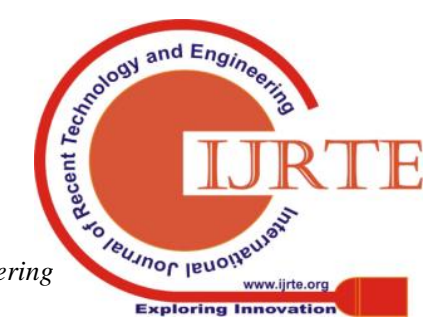


expected to help them to tolerate and deal with stressful situations faced their life [14]. By using effective coping strategies, it also can help the victims to control and manage their emotions, solve the problems and eventually drive themselves to overcome the crisis (flood disaster) [15]. Therefore, it is important to identify the types of coping strategies used by the flood victims to reduce their emotional distress which assist them to achieve their physical and psychological well-being.

The findings showed that there are four coping strategies used by the informants during crisis namely, problem focused coping, emotion focused coping, religious coping and maladaptive coping strategy; which will be microscopically explored in this section.

\section{A. Problem Focused Coping Strategy}

There are few informants in this study used problem focused coping method when facing the post-incident (after flood) problems. According to Informant 5, after identifying financial as the main problem, he took initiative to find the possible solutions to overcome the financial constraint. Hence, he looked for some business opportunities at the night and weekend market. The informant also found an alternative by getting some amount as a loan from Amanah Ikhtiar Malaysia (a private trust body that offers microcredit financing scheme) to buy a van for transportation purposes and also as a capital for his new venture (business at market). Below are example responses from the informants of this current study;

"...After the floods, it was so depressed when I think about money. Me and family, we were lost everything. But I know that I need to do something for my family. Then I start thinking to sell something at the night market and weekend market. For me it's an opportunity to find money. So I make an AIM loan to start my business. I then bought a van to manage my business. For me it is the best way to solve my financial problems after the flood... and it's work..."

(Informant 5)

Similarly, with Informant 19 , in order to avoid the stress of financial needs after the flood, informant decided to sell food and drinks to survive. Although the informant knew he did not gain much profit from the business but he knew that it was the best solution for him to temporarily overcome the financial problem. The informant chose to sell food and drinks items as he aware on the minimal educational qualification that he has and hence, the informant found that running a small business seemed to be the immediate effort that he could take to financially support his family. The verbatim of Informant 19 as below;

“... Currently I'm selling food and drinks instead of doing nothing. Yes, it true, I didn't earn much profit from that but I believe that's only thing that I can do to make sure that I can survive after the floods. Plus, I don't have any specific skill in certain work even I don't have higher education background. And trust me, it's not an easy to get a new job after the flood disasters. So far, this is the best that I can do to get money and support my daily life ..."

(Informant 19)
Steps taken by Informant 5 and Informant 19 clearly indicated that 'problem focused coping strategy' (solution focused) as one of the coping strategies used by them to overcome their financial problems. The problem focused coping strategy is a method of facing the problem by changing the source of stress with immediate actions [16]. This strategy relies on using active ways to directly tackle the situation that caused the stress. Informant who used this type of coping strategy normally will analyze the problem and situation and eventually change the source of stressors by taking immediate actions to reduce their stress.

Previous studies also showed that there was a positive relationship between the 'problem focused coping strategy' and the well-being of research respondents in which individuals who used the 'problem focused coping' tend to be more optimistic compared to their counterparts [17]. This is because individuals who were in the stress situations will try their best to solve their problems with the aim to maintain their well-being. As such, it was clear that the ability to achieve the well-being much depends on the use of 'problem focused coping strategy'.

\section{B. Emotional Focused Coping Strategy}

The findings showed that there are few informants in this study used 'emotional focused coping' when facing their problems after the flood incident. According to Informant 13, he managed to control his negative emotion such as fear, anxiety and depression by changing his mind to positive thinking. The informant believed that prolong sadness will not be able to return his house and properties. Therefore, the informant decided to see things positively. The informant also admitted that he did not see the flood as calamity. The response from the Informant 15 is stated below;

“...It is really sad when you lose everything but I try not to think it as a burden. I did not see the flood as catastrophe or disaster because I'm sure that something happens for a reason and that make me more calm ..." (Informant 13)

Positive reappraisal is one of the techniques in managing emotional stress. By managing the stress well, it can help the person feel better physically and emotionally [18]. Even it was admitted that it will not solve the problems, but this coping strategy is able to help the individuals to remain resilient in overcoming the problems after the disasters [19] Cognitive reframing allows the flood victim to shift the way they see a problem, which can actually make the difference between whether or not they feel stressed by facing it. Reframing is more about seeing solution, benefits and new perspectives to problem that they face. It can help them to cultivate more positive feeling which can help them to feel less stress.

Meanwhile according to Informant 17, to prevent herself from experiencing emotional distress, she decided to do as much work as possible. Informant also mentions that, if she occupied with many works, then she would not have time to think about her loss (house and properties). The informant will keep herself busy to avoid sadness and emotional distress. The following is the 
informant's statement on this matter;

“... I did a lot of work to keep myself from being sad. When I busy with my works I do not have time to think about the loss and destruction that I experienced. That's why I choose to keep myself busy to avoid unpleasant feeling..."

(Informant 17)

In this situation, the informant aimed to manage the emotion associated with the situation rather than changing the situation itself. This coping is a type of stress management that attempts to minimize negative emotion responses that occur when exposed to stressors. Similarly, Informant 24 chooses to accept the situation and avoid thinking about the sadness from the tragedy of flooding. By accepting what had happened, the informant admitted to be calmer in facing the problems after the flood. Here is an interview quote of the informant on this matter;

\section{"...Instead of think about the sadness experienced, I rather to accept what was happen and I decided to move on and continue my life as usual. I don't like to think a lot, it just made me headache. So I prefer to accept what happened and it's truly makes me more calm!" \\ (Informant 24)}

Acceptance is an individual response to accept the stress situation and it is considered as one of the technique that can be used in emotional focused coping. It is a stress management strategy in which the individual focuses on regulating their negative emotional reactions to a stressor. Instead of taking actions to change the stressor itself, the individual tries to control their feeling using a variety of behavioral and cognitive tools [19]. From this study, the informants who used the 'emotional focused coping strategy' showed less emotional problems as they were able to manage their emotions that further prevent from being aggressive. This finding is in line with the previous study as individuals who used 'emotion focused coping strategy' showed less anxiety problems, depressions and low aggressive behavior compared to others [20]. By using emotional focused coping strategies, it can help the individual to reduce health risks and at the same time promote health resiliency among them.

\section{Religious Coping Strategy}

The findings showed that there are few informants in this study used the 'religious coping strategy' to cope with crisis situation through the comfort found in spiritual and religious practices. There are two type of religious coping used by informants; positive religious coping and negative religious coping. According to Informant 3, she used the negative religious coping where she argued why God allow the damages of her house. She assumed that God was cruel towards her by saying that the flood made her family in misery. The informant tends to show her anger by expressing dissatisfaction and disappointment towards God. She channeled her stress to God without taking personal responsibility for the situation. The following is informant's statement about this matter;

"...I know the God control everything but sometimes I wonder why God took my home. This is the most important thing for me and my family. I think God is cruel to me... Do God wanted to punish me? And why it's happens to me? My life is so difficult right now. God is doing unfair to me ..."

(Informant 3)

As a result, the informant showed psychological disorder and she had a problem in adjusting her life after the flood. The informant who used this negative religious coping even had doubt regarding issues of God and faith by questioning, criticizing and showing disagreement on what happened to them. This coping correlated with negative psychological adjustment such as anxiety and negative mood [21].

However, it is contradictory with positive religious coping. According to the informant 7 , if she felt sad, she will pray immediately and ask God for calmness. She was confident that if human get closer to God, they will be helped and God will ease their journey (spiritual connection). It involves an active and internalized personal exchange with God. Here is an interview quote of the informant on this matter;

“...When I am sad, I always remember God. I beg for peace. That's what I always do. I believe in God provision. If we keep our relationship with God, God will take care of us. God will give us peace..."

(Informant 7)

Informant 27 also described the same thing as she always goes to the mosque and performs prayers. After the flood, the informant realized that she became closer to God. That helps her to survive and remain resilience after the flood incident.

"...After the flood I always go to the mosque. God help me a lot. He gave me strength to deal with all this. Sometime I woke up early morning for prayers. Request peace from God. I believe God helped me by giving me strength to survive..."

(Informant 27)

This finding showed spiritual and religious coping strategies helped the flood victims to increase their resilience. Those who have high resiliency are able to reduce the trauma and it is correlated strongly with positive psychological adjustment by showing happiness and acceptance. While, previous researcher agreed and stated that the beliefs towards religion and spiritual elements provide emotion calmness to those who believe in it especially when they were facing crisis situation such as disasters [22].

\section{Maladaptive Coping Strategy}

Majority of the informants in this study used maladaptive coping strategy. The findings showed that there are three maladaptive behaviors showed by the informants namely venting emotion, behavioral disengagement and mental disengagement. For venting emotion, informant tent to express their inner feelings or negative emotion such as anger, sadness, disappointment, frustration and other unpleasant emotions towards themselves (self-blame), angry with the situation they were facing and some express their anger to others (venting to others). According to Informant 10, she was sad with the loss and destruction due to the flood. She blamed herself for not taking immediate action 
during the flood that made her family lost everything. She admitted that she felt very guilty. Here is an interview quote of the informant about this matter;

“... till now, I couldn't forgive myself, if I took immediate action during the event I will definitely not lose everything. This happen because of my fault. If I could turn back time, surely my family will not loss everything. I really feel sad and couldn't accept it..."

(Informant 10)

Meanwhile behavioral disengagement can be seen when Informant 12 mention that he lost his business due to the flood. Informant admitted that he did not intend to find another job because he was frustrated. After the flood, he admitted that he isolated himself from seeing anyone because he felt embarrassed, sad and frustrated with what had happened. The following is informant's statement on this matter;

"...I suffered a huge loss in the flood. And I feel so bad. Currently I'm not working and I prefer to stay at home. Even I do not want to meet other people because I feel embarrassed, sad and frustrated with the fate that I am facing ..."

(Informant 12)

Informant admitted that he attempts to have social withdrawal in order to escape from stress situation. This type of avoidant behavior is considered maladaptive coping strategy that is often used to reduce one's anxiety yet the results is dysfunctional and non-productive outcomes. In this context, informant actually is seeming to be harmful than helpful.

Similarly, to Informant 1 , she tried to avoid herself from stress situation by taking a sleep at late night to avoid facing the day. Informant hoping that when she wakes up, the problem will be settled. The informant forgot that sleeping only offers a temporary escape from their problem. This coping strategy is expected to trigger more stress. Here is an interview quote of the informant about this matter;

“... I prefer not to think too much on my problem because it's just made me headache. Normally instead of thinking about it hardly, I just go sleep. Or sometime I sleep late night watching television. When I woke up, I was hoping that the problem would go away and far away from me but the fact it wasn't ..."

(Informant 1)

One of the most common ways that informant cope with the stressful situation after the flood is by using mental disengagement as maladaptive coping strategy. For Informant 25 , she admitted that she always dreams of magic thinking and hoping that a miracle will happen to solve her problems such as be given a new house, new vehicle, money and new life so that she can continue her life as usual. According to Informant 25:

"...I really hope that all the hardships that I've experienced will end soon. Sometimes I expect a miracle to happen where I will get a new home, new cars, or some one give me money so that I can start a new business. But I know it's just my dreaming..."

(Informant 25)
The informant who used these types of coping tends to reduce their stress and anxiety but it may result to unproductive behavior and there was even a potential for social dysfunctional. This maladaptive behavior can hinder a person's ability to adjust them in a certain situation. This coping strategy only affective for a short term but it does not work to help an individual to overcome the stress in long term. It is considering as an unproductive behavior because the person is actually did not do anything to reduce their stress.

In certain situations, venting emotion sometimes can be beneficial to cure the emotion [23]. However, it can also create negative effect if it is prolonged and added by other stressor. Generally venting emotion is not effective to be used repeatedly because it will increase the affliction and distress to those who is having a crisis in life [24]. On the other hand, if the person expresses the negative emotion as the verbal focus, against the negative experience that is conceptualized as the cognitive summary, the person will always be related with a higher level of depression.

Although behavior disengagement is generally seen as a strategy to avoid from any action (maladaptive behavior), but the previous studies showed that in the context of cancer patients, the behavior disengagement might be an adjusting reaction towards the reality of death. The patient who knows that he will die from his cancer will withdraw from his social life and look at the end of his life and hoping that it will end with peace [25]. They will not aggressively participate in overcoming their illness [26] However, this coping is not suitable to person who is involved with a disaster because life still needs to be continued and it depends mostly on the coping strategy that used by the flood victims. It is very important to ensure that they can functions well to achieve physical and psychological well-being after the flood.

Besides, there are informants in this study used mental disengagement as maladaptive coping strategy. Mental disengagement occurred to reduce the stressor. The past studies showed that mental disengagement coping did not give any advantage to the individual in reduce the stressor. Therefore, mental and behavioral disengagement lead to the disturbance in the flood victims' life. The theory of crisis intervention [27] suggested that the elimination of maladaptive coping strategy is the main focus of crisis intervention in increasing the resiliency of the flood victims.

It is suggested to use cognitive behavioral therapy (CBT) in order to change maladaptive coping strategy since the findings indicated that this type of coping is negative but used by majority of informant. CBT is types of psychotherapeutic treatment that can help flood victims understand the thoughts and feelings that influence their behaviours. It is a talking therapy that can help flood victims manage their problems by changing the way they think and behave. CBT is most commonly used to treat anxiety and depression and other mental health issues. CBT can have used by helping profession (psychologist, counsellor and social worker) to teaches their client (disaster victims) to identify, evaluate and respond to their dysfunctional thoughts and beliefs. It uses a variety of techniques to change thinking, mood and behaviour. The goal of CBT is to allow a client to take control of their problems and to mange life in a healthy adaptive way.

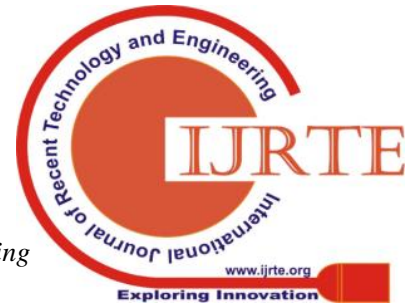




\section{Exploring the Coping Strategies that Improve Resiliency among Flood Victims in Kelantan, Malaysia}

\section{CONCLUSION}

In conclusion, there are four coping strategies used by the informants in this study, namely problem focused coping, emotion focused coping, religious coping and maladaptive coping. The coping skills used by the flood victims were crucial to overcome a crisis situation such as disaster. Crisis is a perception of an event or difficult situation that limits an individual resource [27]. In this case, coping strategy is considered as individual resource. Therefore, Crisis Intervention Theory suggests that perception (cognitive) on the situation that happened needs to be changed. If the victim sees the crisis (disaster) as an opportunity, it will effectively increase the coping skill in facing crisis in the future. Proactive coping strategies can be an effective way to manage the future obstacles and help people deal with unexpected situation such as disasters. The researcher found that the informant who uses the problem focused coping, emotion focused coping and positive religious coping has high resilience and able to solve their problems effectively compared to informant who uses the negative religious coping and maladaptive coping. By using the effective coping strategy, it helps an individual to solve problem, control their emotion and guide them towards achieving goal in overcoming the crisis. This will increase their physical and psychosocial well-being.

\section{REFERENCES}

1. Economic Planning Unit (EPU), State of Kelantan. (Conferences paper) Kelantan Flood Management Conference 2015: Resolution and framework for sustainable development. Kubang Kerian, Kelantan: University of Sciences Malaysia. 2015.

2. G. Sikh. Reflections From Flooding Events in Kelantan. (Conference Paper) Kelantan Mental Health Conferences. Kelantan: Kelantan State Health Department. 2015.

3. M. A. Noremy, A. Azlinda, H. Nazirah \& M. A. Nur Hafizah. (2017). Investigation of flood victim's problem during flood disaster December 2014 in Kelantan, Journal of Social Sciences and Humanity, 14 (5), $1-19$.

4. K. A. Becker-Blease, H. A. Turner \& D. Finkelhor. (2010). Disaster, victimization and children' mental health. Child Development 81(4), 1040-1052. doi:10.1111/j.1467-8624.2010.01453.x

5. C. T. Taft, C. M. Monson, J. A. Schumm, L. E. Watkins, J. Panuzio \& P. A. Resick. (2009). Posttraumatic stress disorder symptoms, relationship adjustment, and relationship aggression in a sample of female flood victims. Journal Family Violence, 24, 389-396.

6. M. K. Lindell \& C. S. Prater (2004). Assessing community impacts of natural disasters. Natural Hazards Review, 4(4), 176-186. doi:10.1061/(ASCE)1527-6988(2003)4;4(176).

7. H. Muzairi, M. N. Mohd Zawari \& W.M. Wan Nor Arifin,. Exploring emotion disasters and resilience in adolescent affected by flood in Kelantan and the development of peer support group for trauma module. Final Report of the 2014 Flood Disaster Research (Conference paper) Part 1 Socio Economic, pp. 244-247. University of Technology Malaysia: Ministry of Higher Education. 2015.

8. Y. Norizan (2016). Management of psychological elements in disaster preparedness: A qualitative study of flood victims in Kelantan. Malaysian Journal of Psychology, 30(2), 74-81. URL: http://spaj.ukm.my/ppppm/jpm/issue/view/26

9. M. A. Nur Saadah, A. K. Nor Ba'yah, A. R. Roseliza Murni, A. Hilwa, M. A. Noor Amalina. Assistance and disaster preparedness: Evaluation of resilient attributes to promote mental health among adolescents and adults of flood victims in Kelantan. Final Report of the Flood Risk Research Conference 2014. (Conference paper) Part 2 Health \& Clinical Sciences, pp.282-284. University of Technology Malaysia: Ministry of Higher Education. 2015.

10. M. T. Siti Uzairiah. Qualitative Study and Interview Analysis. Kuala Lumpur, Malaysia: Aras Publisher. 2017

11. Y. Norizan, Y. (2016). Management of psychological elements in disaster preparedness: A qualitative study of flood victims in Kelantan. Malaysian Journal of Psychology, 30 (2), 74-81.
URL: http://spaj.ukm.my/ppppm/jpm/issue/view/26

12. A. Zainuddin. Research Methodology and Data Analysis (Second ed.). Malaysia: UiTM Press. 2012.

13. V. Braun \& V. Clarke. (2006). Using thematic analysis in psychology. Qualitative Research in Psychology, 3(2),77-101. doi:10.1191/1478088706qp063oa

14. J. P. Chaplin. Complete Psychology Dictionary. Jakarta: Raja Grafindo Persada. 2004.

15. S. P. Brown, G. Challagalla \& R. A. Westbrook. (2005). Good cope, bad cope: Adaptive and maladaptive coping strategies following a critical negative work event. Journal of Applied Psychology, 90(4), 792-798. doi:10.1037/0021-9010.90.4.792

16. S. Folkman, R.S. Lazarus, R. J. Gruen \& A. Logis (1986). Appraisal, coping, health status and psychological symptoms. In K. Gelbrich. Anger, frustration, and helplessness after service failure: Coping strategies and effective informational support, Journal of the Academy of Marketing Science, 38, 567-585. doi:10.1007/s11747-009-0169-6.

17. O. Sarid, O. Anson, A. Yaari \& M. Margalith (2004). Coping styles and changes in humoural reaction during academics stress. Health and Medicine, 9, 85-98. doi:10.1080/13548500310001637779

18. R. S. Lazarus \& S. Folkman. (1984). Stress, appraisal and coping. In C S. Carver, M. F. Scheier \& J. K.Weintraub. Assessing coping strategies: A theoretically based approach. Journal of Personality and Social Psychology, 56(2), 267-283.

19. V. Khoshtinat. (2012). A review on relationship between religion, spirituality, spiritual transcendent, spiritual intelligence with religious coping. International Research Journal of Applied and Basic Sciences, 3(9), 1916-1934.

20. M. E. Wadsworth \& B. E. Compa (2002). Coping with family conflict and economic strain: The adolescent perspective. Journal of Adolescent 12, 243-274. doi:10.1111/1532-7795.00033

21. G. G. Ano \& E. B. Vasconcelles. (2005). Religious coping and psychological adjustment to stress: A meta-analysis. Journal Clinical Psychology, 61, 1-20. doi:10.1002/jclp.20049

22. L. R. Wang, S. C. Chen \& J. Chen (2013). Community resilience after disaster in Taiwan: A case study of Jialan Village with the strengths perspective. Journal of Social Work in Disability \& Rehabilitation, 12 (1-2), 84-101. doi: 10.1080/1536710X.2013.784551

23. T. Lischetzke \& M. Eid (2003). Is attention to feeling beneficial or detrimental to affective well-being? Mood regulation as a moderator variable. Emotion Journal, 3, 361-377. doi: 10.1037/1528-3542.3.4.361

24. E. Ashton, M. Vosvick, M. Chesney, G. F. Cheryl, C. Koopman, K. O'shea, J. Maldonado, M. H. Bachmann, D. Israelski, J. Flamm, D. Spiegel (2005). Social support and maladaptive coping as predictors of the change in physical health symptoms among persons living with HIV/AIDS. AIDS Patient and STDs, 19 (9), 587-598. doi:10.1089/apc.2005.19.587

25. T. F. Hack \& L. F. Degner. (2004). Coping responses following breast cancer diagnosis predict psychological adjustment three years later. Psychooncology, 13, 235-47. doi:10.1002/pon.739

26. K. M. Paul, C. P. Andrea, L. K. Elizabeth, A. B. Tracy, B. Michael, A. W. Alexi, P. William \& G. P. Holly. (2012). Religious coping and behavioral disengagement: Opposing influences on advance care planning and receipt of intensive care near death. Psychooncology, 21(7), 714-723. doi:10.1002/pon.1967.

27. K. Kanel. A Guide to Crisis Intervention ( ${ }^{\text {rd }}$ ed.). California: Thomson Brooks Cole. 2007.

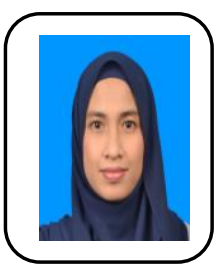

\section{AUTHORS PROFILE}

Noremy Md Ahir is a Senior Lecturer at Faculty of Social Sciences and Humanity, National University of Malaysia. She was completed her Master Degree and Doctor Philosophy $(\mathrm{PhD})$ in Social Work from University of Sciences Malaysia. Her research interes mainly in psychological issues, crisis intervention and disaster management specifically in social work perspective. 
Mohammad Rahim Kamaluddin is a Senior Lecturer and Criminologist (with Doctoral Degree qualification) at Human and Societal Well-Being Centre, Faculty of Social Sciences and Humanities, National University of Malaysia.

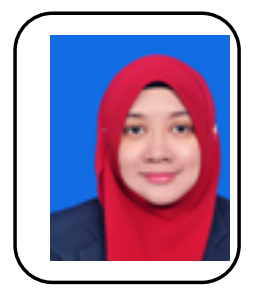

Aizan Sofia Amin is a Senior Lecturer at the Faculty of Social Sciences and Humanities, National University of Malaysia. She holds a Doctorate of Philosophy in the field of Disability Studies at the University of Glasgow, United Kingdom. Her areas of expertise in disability studies, counselling psychology and social work.

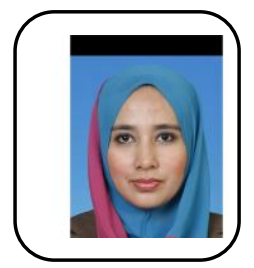

Rusyda Helma Mohd is a Lecturer at Faculty of Social Sciences and Humanities, National University of Malaysia. Currently, she is pursuing her Higher Degree by Research at The University of Western Australia in safety behaviour and human resources management.

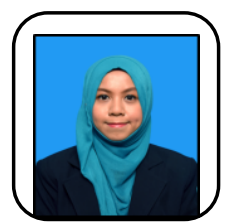

Nur Hafizah Md Akhir is a post graduate student at School of Social Sciences, University of Sciences Malaysia. Currently, she is pursuing her $\mathrm{PhD}$ Degree by Research in disaster volunteerism specifically on social work perspective. 